\title{
ANALISIS KEMAMPUAN PEMAHAMAN DAN PEMECAHANMASALAH MATEMATIK SISWA MTs PADA MATERI BANGUN RUANG SISI DATAR
}

\author{
Kusnita Damar Sari ${ }^{1}$, Rismayanti ${ }^{2}$, Indah Puspitasari ${ }^{3}$ \\ 1, 2, ${ }^{3}$ Pendidikan matematika IKIP Siliwangi, Cimahi \\ kㅡzznitazari@gmail.com, ${ }^{2}$ rismay58@gmail.com, 3 3indah@ikipsiliwangi.ac.id
}

\begin{abstract}
Mathematical cognitive abilities that must be possessed by students one of them is the ability to understand mathematics and mathematical poblem solving. The pupose of this study is to determine the extent to which the ability and solving mathematical problems that students have. The research method used is qualitatve descriptive with sampel nineteen students class IX MTs in Cianjur egency. The test instrument was given five questions of mathematical comprehension and five problems of mathematical problem solving test. Based on the results of ability to comprehend and solve mathematical problems, the understanding and problem solving skills of MTs students in Cianjur regency is still low.
\end{abstract}

Keywords: Mathematic comprehension, Mathematic problem solving

\begin{abstract}
Abstrak
Kemampuan kognitif matematis yang harus dimiliki oleh siswa salah satunya adalah kemampuan pemahaman matematik dan pemecahan masalah matematik. Tujuan dari penelitian ini adalah untuk mengetahui sejauh mana kemampuan pemahaman dan pemecahan masalah matematik yang dimiliki siswa. Metode penelitian yang digunakan ialah kualitatif deskriptif dengan sempel sembilan belas siswa kelas IX MTs di Kabupaten Cianjur. Instrumen tes yang diberkian sebanyak lima soal tes kemampuan pemahaman matematik dan lima soal tes kemampuan pemecahahan masalah matematik. Berdasarkan hasil tes kemampuan pemahaman dan pemecahan masalah matematik yang dilakukan, kemampuan pemahaman dan pemecahan masalah matematik siswa MTs di Kabupaten Cianjur masih tergolong rendah.
\end{abstract}

Kata Kunci: Pemahaman matematik, pemecahan masalah matematik

How to cite: Sari, K. D., Rismayanti, \& Puspitasari, I. (2018). Analisis Kemampuan Pemahaman dan Pemecahan masalah Matematik Siswa MTs pada Materi Bangun Ruang Sisi Datar. JPMI - Jurnal Pembelajaran Matematika Inovatif, 1 (5), 965-974.

\section{PENDAHULUAN}

Matematika adalah salah satu cabang ilmu pengetahuan yang mudah ditemukan pada berbagai lini aktivitas manusia. Di dunia pendidikan sendiri, matematika merupakan mata pelajaran wajib diampu oleh setiap siswa, ini tak lepas dari betapa pentingnya matematika itu sendiri, Puspitasari, Purwasih, Nurjaman, \& Wahyuni (2017), mengatakan bahwa aktivitas pembelajaran matematika merupakan suatu proses untuk pembentukan mindsite agar tercipta pola pikir yang sistematis dari yang mudah sampai yang sukar. 
Dalam KTSP 2006 yang disempurnakan pada kurikulum 2013, mencantumkan tujuan pembelajaran matematik sebagai berikut: 1) memahami konsep matematika, 2) menggunakan penalaran pada pola dan sifat, 3) memecahkan masalah, 4) mengkomunikasikan, tujuan diatas menggambarkan kompetensi atau kemampuan berpikir matematik siswa (Hendriana \& Sumarmo, 2014).

Lebih lanjut Bloom (Hendriana \& Sumarmo, 2014) menggolongkan tujuan domain kognitif dalam enam tahap, yaitu: mengetahui atau menghapal (C1), memahami (C2), mengaplikasikan (C3), menganalisis (C4), menyintesis (C5), dan mengevaluasi (C6). Tiga tahap pertama tergolong pada berpikir tingkat rendah dan tiga berikutnya tergolong pada berpikir tingat tinggi. Dengan demikian, kemampuan pemahaman matematika termasuk kedalam kemampuan tingkat rendah.

Pemahaman matematik adalah kemampuan dimana siswa mampu menyerap atau memahami arti dari suatu konsep matematika. Purwanto (Aripin, 2015) mengatakan bahwa pemahaman adalah tingkat kemampuan yang mengharapkan siswa mampu memahami arti atau konsep, situasi serta fakta yang diketahuinya. Pada kenyataannya di lapangan siswa hanya menghapal rumus tanpa mengetahui dari mana rumus tersebut didapat. Kemampuan pemahaman juga merupakan kemampuan awal yang harus dimiliki siswa dalam pembelajaran matematika,agar dapat mengembangkan kemampuan matematik lainnya. Sejalan dengan yang dikemukakan Sariningsih (2014) bahwa kemampuan pemahaman matematis (KPM) penting untuk dimiliki siswa, karena kemampuan tersebut merupakan prasyarat seseorang untuk memiliki kemampuan pemecahan masalah matematis (KPMM), ketika seseorang belajar matematika agar dapat/mampu memahami konsep-konsep, maka saat itulah orang tersebut mulai merintis kemampuan-kemampuan berpikir matematis yang lainnya.

Selain kemampuan pemahaman matematik, salah satu tujuan pembelajaran matematik adalah kemampuan pemecahan masalah atau KPM. Kemampuan pemecahan masalah matematik tak lepas dari dua hal yakni masalah dan pemecahannya. Menurut Nur \& Rahman, (2013), Masalah dalam matematika dapat diartikan sebagai suatu situasi matematis yang belum secara langsung diketahui prosedur pemecahannya tetapi berada di sekitar jangkauan kognitif siswa. Sedangkan menurut Muchlis (2012) pemecahan masalah sebagai usaha mencari jalan keluar dari suatu kesulitan, mencapai suatu tujuan yang tidak begitu saja dengan mudah dapat dicapai.

Di sisi lain, Yuhani, Zanthy, \& Hendriana (2018) menyatakan bahwa pemecahan masalah perlu pengetahuan, kemampuan, kesiapan, kreativitas, serta penerapannya dalam menyelesaikan masalah nyata yang dihadapi siswa sehingga dapat membantu menyelesaikan suatu persoalan. Maka dari itu sangat penting bagi siswa mempunyai kemampuan pemecahan masalah matematik. Dengan terbiasanya siswa dihadapkan dengan masalah yang dihadapi, maka siswa akan terbiasa menggunakan pola pikirnya dalam menghadapi permasalahan yang timbul pada kehidupan sehari-hari (Sundayana, 2016)

Untuk mengukur kemampuan pemahaman dan pemecahan masalah matematik siswa, diperlukan beberapa indikator yang diujikan yaitu: Indikator kemampuan pemahaman matematik yang meliputi; menerapkan suatu konsep, memberikan contoh dan non contoh dan menerapkan konsep algoritma pada pemecahan masalah. Sedangkan indikator pemecahan masalah yang digunakan antara lain; memahami masalah, membuat model matematika dari 
suatu masalah, merancang atau merencanakan strategi untuk menyelesaikan masalah dan memeriksa kembali hasil jawabannya.

Dari paparan diatas, pentingnya pemahaman dan pemecahan masalah matematik tak lepas dari kendala atau kesulitan tersendiri yang dialami oleh siswa. Wahyudin (Rohaeti, 2012), mengatakan bahwa salah satu penyebab siswa lemah dalam matematika adalah kurang memiliki kemampuan untuk memahami (pemahaman) untuk mengenali konsep-konsep dasar matematika (aksiomatik, definisi, kaidah dan teorema) yang berkaitan dengan pokok bahasan yang sedang dibicarakan.

Sesuai dengan hasil wawancara peneliti dengan salah satu guru MTs di Cianjur, penguasaan konsep-konsep dasar pada materi bangun ruang sisi datar masih rendah yang berimbas pada kemampuan siswa dalam menerapkan rumus-rumus bangun ruang sehingga siswa kesulitan memecahkan suatu permsalahn matematika. Pada saat siswa membuat jaring-jaring balok, siswa mengetahui bahwa balok terdiri dari bangun datar dengan sisi-sisi yang berhadapan sama besar. Dari hal tersebut, kita bisa menghitung luas permukaan bangun ruang. Jika siswa ditanya apa rumus mencari luas permukaan, siswa dapat menjawab $2(\mathrm{pl}+\mathrm{pt}+\mathrm{lt})$, tetapi apabila diberikan soal yang diketahui luas permukaan, panjang dan lebar dan yang ditanyakan adalah tinggi, siswa kesulitan untuk menyelesaikan permasalahan tersebut.

Rendahnya kemampuan pemahaman matematik, ditunjukkan oleh hasil penelitian Putra, Setiawan, Nurdianti, Retta, \& Desi (2018) menunjukan presentase kemampuan pemahaman matematik siswa SMP yaitu sebesar $41,67 \%$ siswa berkemampuan rendah, 30,56\% siswa memiliki kemampuan pemahaman sedang dan $27,72 \%$ siswa berkemampuan pemahaman tinggi. Hal ini menunjukan sebagian besar siswa masih memiliki kemampuan pemahaman matematik yang rendah. Tiun, Hudiono, \& Hartoyo (2014) menggolongkan siswa pada tiga kelompok yakni kelompok atas sebesar 49,29\% dengan kemampuan pemecahan masalah tinggi, kelompok tengah sebesar $31 \%$ dengan kemampuan pemecahan masalah sedang dan kelompok bawah sebesar $13,75 \%$ dengan kemampuan pemecahan masalah rendah.

Maka dari itu, tujuan utama penulisan artikel ini adalah untuk mengetahui sejauh mana kemampuan pemahaman matematik dan pemecahan masalah matematik siswa MTs pada materi bangun ruang sisi datar.

\section{METODE}

Jenis penelitian ini adalah penelitian kuantitatif deskriptif, Penelitian kualitatif sendiri adalah suatu penelitian dengan terfokus pada data-data dan pernyataan yang di peroleh dari hasil interaksi antara peneliti, dengan yang ditelitinya dan orang-orang yang ada di tempat penelitian. Pengolahan data diambil dari soal tes dan wawancara langsung terhadap subjek penelitian. Seperti yang diungkapkan Moleong (Dini, Wijaya, \& Sugandi, 2017) dalam pendekatan kualitatif data yang dikumpulkan bukan berupa angka-angka, melainkan data tersebut berasal dari naskah wawancara, catatan lapangan, dokumen pribadi, catatan, memo, dan dokumen resmi lainnya.

Sampel penelitian diambil 19 siswa kelas XI di salah satu MTs Kabupaten Cianjur. Data dalam penelitian ini berupa hasil tes tulis kemampuan pemahaman dan pemecahan masalah matematik. Siswa yang memiliki kemampuan pemahaman dan pemecahan masalah matematik yang baik jika siswa dapat memyelesaikan semuan soal tes dengan benar. Sesuai 
dengan yang dikemukakan Putra et al., (2018) menjelaskan bahwa soal yang diujikan kepada siswa harus memenuhi indikator kemampuan yang ditetapkan.

\section{HASIL DAN PEMBAHASAN}

\section{Hasil}

\section{a. Kemampuan Pemahaman Matematik}

Data kemampuan pemahaman, yang diperoleh dari tes, dianalisis terhadap masing-masing butir soal. Sehingga diperoleh data tes kemampuan pemahaman matematika siswa pada setiap indikator.

Tabel 1. Presentase Kemampuan Pemahaman Matematik Siswa

\begin{tabular}{clc}
\hline $\begin{array}{c}\text { No } \\
\text { Soal }\end{array}$ & \multicolumn{1}{c}{ Indikator } & \multicolumn{1}{c}{$\begin{array}{c}\text { Presentase jumlah Siswa } \\
\text { yang Menjawab Benar }\end{array}$} \\
\hline 1 & Menerapkan ulang suatu konsep & $48,68 \%$ \\
2 & $\begin{array}{l}\text { Memberikan contoh dan non contoh } \\
\text { suatu konsep }\end{array}$ & $65,78 \%$ \\
3 & $\begin{array}{l}\text { Mengaplikasikan suatu konsep atau } \\
\text { algoritma pada pemecahan masalah }\end{array}$ & $22,36 \%$ \\
4 & $\begin{array}{l}\text { Mengaplikasikan suatu konsep atau } \\
\text { algoritma pada pemecahan masalah }\end{array}$ & $14,47 \%$ \\
5 & $\begin{array}{l}\text { Mengaplikasikan suatu konsep atau } \\
\text { algoritma pada pemecahan masalah }\end{array}$ & $43.42 \%$ \\
\hline
\end{tabular}

Berdasarkan Tabel 1 dapat dilihat bahwa skor yang diperoleh siswa berbeda-beda pada setiap indikator. Adapun skor yang didapatkan siswa pada indikator menerapkan ulang suatu konsep sebesar 48,68\%, indikator memberikan contoh dan non contoh sebesar 65,78\%. sedangkan indikator mengaplikasikan suatu konsep atau algoritma pada pemecahan masalah pada soal no tiga $22,36 \%$, no empat $14,47 \%$ dan no lima $43,42 \%$. Dari hasil analisis diatas, sebagian siswa sudah mampu mengerjakan soal tes kemampuan pemahaman dengan baik, namun presentase siswa yang mampu mengerjakan soal tes dengan baik masih tergolong rendah.

\section{b. Kemampuan Pemecahan Masalah Matematik}

Tes kemampuan pemecahan masalah matematik yang diberikan kepada siswa, memuat keempat indikator pemecahan masalah. Pada masing-masing soal yaitu memahami masalah, membuat model matematika dari suatu masalah matematik, merencanakan atau merancang strategi untuk menyelesaikan masalah dan memeriksa kebenaran hasil atau jawaban.

Adapun data kemampuan pemahaman, yang diperoleh dari tes, dianalisis terhadap masingmasing butir soal, seperti pada tabel di bawah ini! 
Tabel 2. Presentase Kemampuan Pemecahan Masalah Matematik Siswa

\begin{tabular}{ccccc}
\hline No Soal & \multicolumn{4}{c}{ Indikator Kemampuan Pemecahan Masalah Matematik } \\
\hline 6 & A & B & C & d \\
\hline 7 & $36,84 \%$ & $26,31 \%$ & $10,52 \%$ & $5,26 \%$ \\
8 & $5,26 \%$ & $0 \%$ & $0 \%$ & $0 \%$ \\
9 & $5,26 \%$ & $0 \%$ & $0 \%$ & $0 \%$ \\
10 & $21,05 \%$ & $0 \%$ & $0 \%$ & $0 \%$ \\
Rerata & $5,26 \%$ & $15,76 \%$ & $0 \%$ & $0 \%$ \\
\hline
\end{tabular}

Keterangan:

A: Memahami masalah

B: Membuat model matematika dari suatu masalah matematik

C: Merencanakan atau merancang strategi untuk menyelesaikan masalah

D: Memeriksa kembali hasil jawaban

Terlihat pada tabel 2 hanya indikator pemecahan masalah pertama yakni memahami masalah, memiliki rata-rata tertinggi dari semua indikator pemecahan masalah yang diujikan yaitu $14,734 \%$. Hal ini menunjukan bahwa presentase kemampuan siswa dalam mengerjakan soal tes kemampuan pemecahan masalah matematik pada setiap indikator masih tergolong rendah.

\section{Pembahasan}

Sebelumnya telah dijabarkan presentase kemampuan siswa dalam mengerjakan soal tes pemahaman maupun pemecahan masalah matematik. Pada soal tes kemampuan pemahaman matematik presentase siswa yang menjawab dengan benar masih tergolong rendah, dari 3 indikator yang ada hanya ada satu indikator yang diatas 50\% sedangkan sisanya berada pada di bawah 50\%. Sedangkan pada soal tes kemampuan pemecahan masalah matematik terlihat bahwa presentase siswa yang dapat memenuhi setiap indikator pada setiap soal tergolong sangat rendah dengan presentase tertingginya hanya sebesar $14,73 \%$ dengan indikator mamahami masalah pada soal. Dengan demikian dapat diduga bahwa siswa masih mengalami kesulitan dalam mengerjakan soal tes kemampuan pemahaman dan pemecahan masalah matematik. Adapun analisis kesalahan yang sering siswa lakukan pada pengerjaannya antara lain:

\section{a. Kemampuan Pemahaman Matematik}

Dari data yang telah di sajikan sebelumnya presentase kemampuan pemahaman matematik siswa masih tergolong rendah. Adapun beberapa kendala yang dihadapi siswa dalam menjawab soal tes diantaranya:

Soal no 1 indikator menerapkan ulang suatu konsep

Jelaskan definisi dari Kubus, Balok, Prisma dan Limas! 


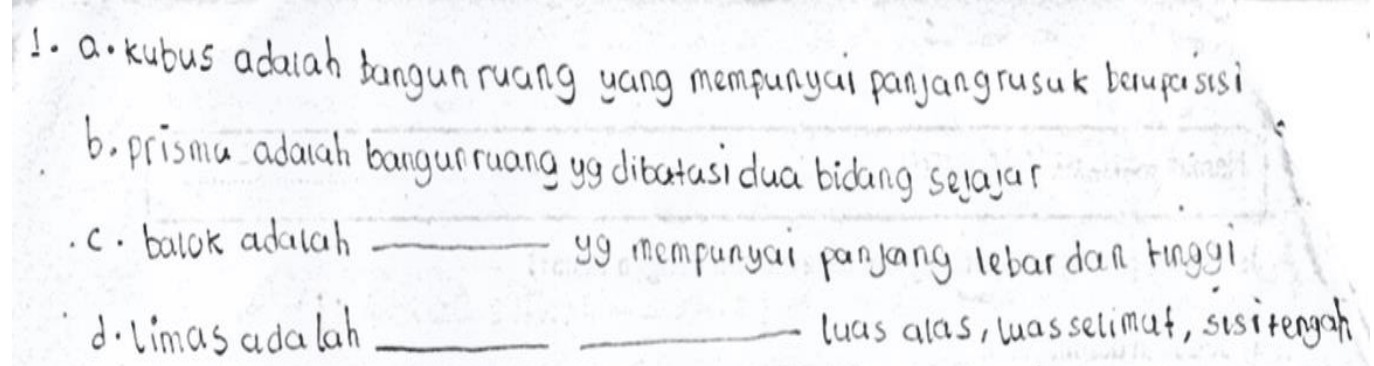

Gambar 1. jawaban siswa soal no 1

Berdasarkan jawaban siswa pada Gambar 1, terlihat bahwa adanya miskonsepsi antara definisi dari setiap bangun ruang sisi datar dengan unsur-unsur dari bangun ruang sisi datar tersebut. Siswa belum bisa menjabarkan secara khusus mengenai setiap bangun ruang sisi datar yang ada.

Soal no 2 dengan indikator Memberikan contoh dan non contoh suatu konsep

Perhatikan gambar di bawah ini dan jawablah pertanyaan-pertanyaan berikut!

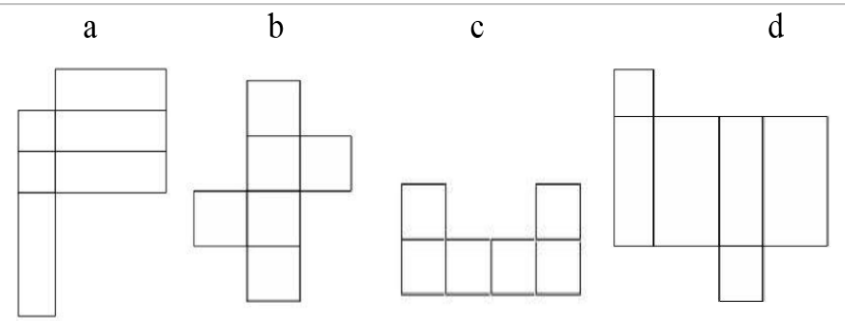

Dari gambar jaring-jaring diatas dapatkah membentuk sebuah bangun ruang? Bangun ruang apakah itu?
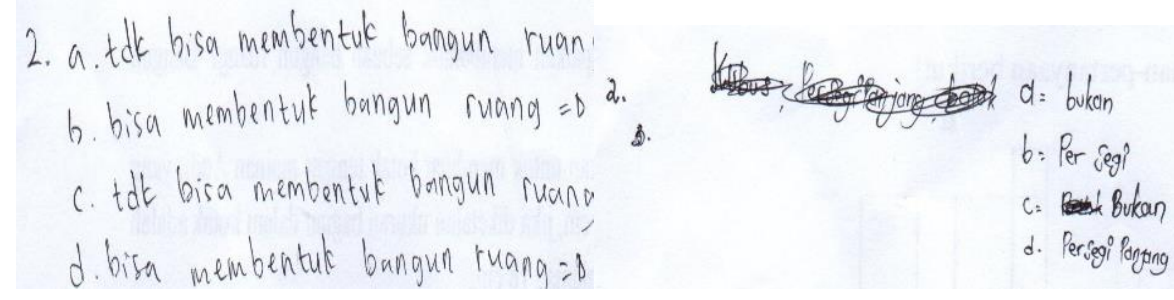

Gambar 2. jawaban siswa soal no 2 siswa 1 Gambar 3. jawaban siswa soal no 2 siswa 3

Pada Gambar 2 siswa sudah mampu menentukan jaring-jaring sebuah bangun ruang sisi datar namun masih belum dapat menentukan bangun ruang sisi datar apa yang terbentuk dengan jaring-jaring yang telah dipilihnya. Sedangkan pada gambar 3 terlihat bahwa siswa belum bisa membedakan bangun ruang sisi datar dengan bangun datar. Hal ini menunjukan siswa masih belum mampu untuk memberikan contoh dan non contoh pada jaring-jaring bangun ruang sisi datar.

\section{Soal no 3 indikator menerapkan ulang suatu konsep}

Tentukan volume kayu yang digunakan untuk membuat kotak tempat mainan Andi, yang berbentuk balok, dengan ketebalan $2 \mathrm{~cm}$, jika diketahui ukuran bagian dalam kotak adalah panjang $54 \mathrm{~cm}$, lebar $46 \mathrm{~cm}$, dan kedalaman $18 \mathrm{~cm}$ ! 


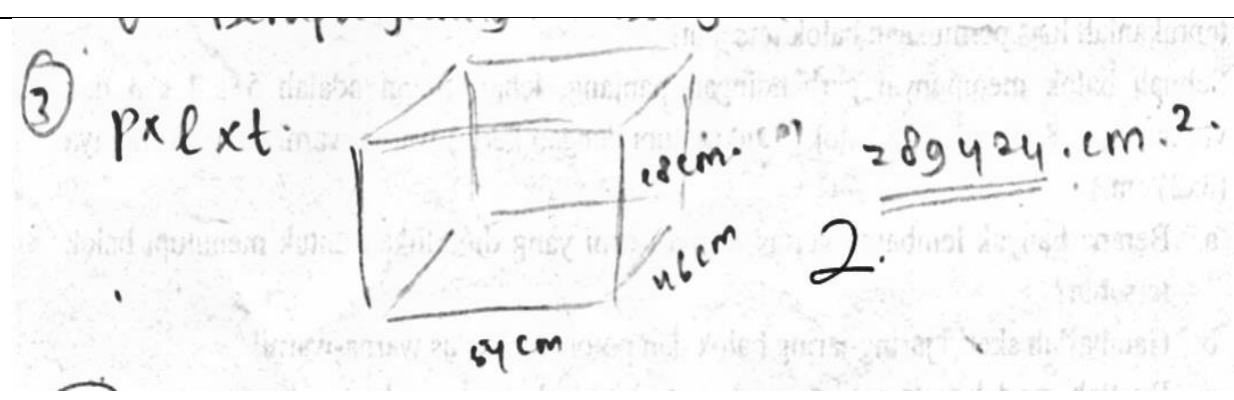

Gambar 4. jawaban siswa soal no 3

Kesalahan siswa pada soal no tiga diakibatkan kecerobohan dalam membaca dan menelaah soal, sekitar 22,36\% skor siswa pada indikator ini. Pada soal no 3 siswa menjawab dengan menghitung volume keseluruhan kotak mainan sedangkan yang di tanyakan ialah volume dari kayu yang digunakan untuk kotak mainan.

b. Kemampuan Pemecahan Masalah Matematik

Kemampuan pemecahan masalah dikatakan tercapai apabila memenuhi indikator-indikator pemecahan masalah yang telah dijabarkan pada halaman sebelumnya, berdasarkan hasil didapat analisis berikut:

Soal no 6 kemampuan pemecahan masalah matematik

Sebuah balok mempunyai perbandingan panjang, lebar, tinggi adalah 5: 4: 3 dan volumenya $3840 \mathrm{~cm}^{3}$. Jika balok akan ditutupi dengan kertas warna-warni yang ukurannya $(3 \times 3) \mathrm{cm}$.

- Berapa banyak kertas warna-warni yang diperlukan untuk menutupi balok tersebut?

- Gambarlah sketsa jaring-jaring balok dan potongan kertas warna-warni!

- Buatlah model matematika untuk menghitung banyaknya kertas warna-warni yang dibutuhkan? Lalu berapakah luas kertas warna-warni yang tersisa?

- Konsep matematika apa yang terlihat dalam permasalahan matematika tersebut?

- Periksalah kebenaran jawaban yang telah dikerjakan!

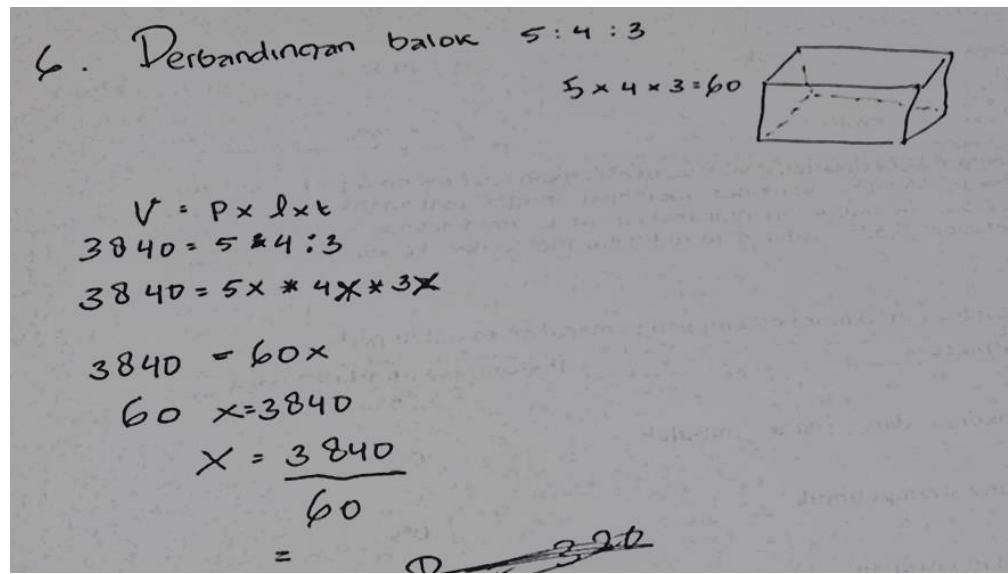

Gambar 5. Jawaban siswa soal no 6

Dalam gambar 5, siswa mulai bisa memahami arah penyelesaian masalah. Siswa melaksanakan perhitungan dengan mencoba-coba, namun siswa masih belum bisa merancang strategi untuk menyelesaikan masalah tersebut. Pada indikator membuat model matematika dari suatu masalah matematik, hanya sebagian kecil siswa yang dapat menyelesaikannnya, terlihat dari nilai persentase sebesar $36,84 \%$, pada indikator membuat model matematika dari suatu masalah matematika presentase sebesar 26,31\%, indikator selanjutnya yaitu 
merencanakan atau merancang strategi untuk menyelesaikan masalah memiliki presentase rata-rata siswa sebesar $10,52 \%$, dari indikator memeriksa kebenaran hasil memiliki presentase $5,26 \%$. Dari 5 soal yang disediakan, siswa hanya mampu mengerjakan soal 6 dan soal 10 saja.

Pada indikator memeriksa jawaban kebenaran hasil, presentase yang didapat sangat kecil. Sebagian besar siswa ketika selesai mnegerjakan sebuah soal tidak pernah memeriksa kembali hasil yang didapatkan, terkecuali siswa memiliki banyak waktu untuk memeriksa kembali. Seperti pada penelitian Sari, Elniati, \& Fauzan (2014) setelah menyelesaikan permasalahan, siswa harus melakukan pengecekan terhadap pekerjaan mereka untuk meyakinkan kebenaran langkah-langkah dan penyelesaian yang didapatkan. Sebagian besar siswa mengungkapkan bahwa mereka hanya melakukan pengecekan apabila merasa ragu terhadap hasil yang diperoleh. Jika pengecekan kembali tidak dilakukan, maka penyelesaian yang diperoleh siswa belum sesuai dengan persyaratan yang terdapat di soal. Imbasnya presentase ketuntasan siswa dalam mneyelsaiakn soal pemecahan masalah masih rendah.

Dari hasil dan analisis kesalahan siswa yang telah dijabarkan sebelumnya dapat dilihat hubungan antara kemampuan pemahaman dan pemecahan masalah matematik terdapat dari proses penyelesaian soal kemampuan pemecahan masalah. Bahwa siswa tidak akan mudah menyelesaikan suatu soal pemecahan masalah, tanpa memahami masalah yang harus diselesaikan. Seperti yang dikemukakan oleh Agus, Artana, Wirya, \& Wibawa (2014) Jika siswa tidak mampu memahami materi pelajaran dengan baik, maka mereka akan mengalami kesulitan dalam memahami masalah matematika dan merencanakan strategi penyelesaian terhadap permasalahan yang diberikan, sehingga pada akhirnya tidak mampu menyelesaikan permasalahan matematika tersebut.

Apabila kita lihat perbedaan tabel kemampuan pemahaman dan pemecahan masalah matematik, sebagian besar siswa tidak mampu menyelesaikan soal kemampuan pemecahan masalah matematik. Mulyanti, Yani, \& Amelia, (2018) dalam penelitiannya mengatakan bahwa dalam menyelesaikan soal kemampuan pemecahan masalah matematik, siswa kurang terampil dan mengaitkan dari satu situasi ke situasi yang lainnya dan kurang memahami masalah yang diberikan. Dengan demikian pemahaman siswa dalam memahami masalah, merencanakan perhitungan, untuk menyelesaikan persoalan masih tergolong kurang.

Sementara Hutajulu (Murnaka \& Dewi, 2018) mengatakan bahwa siswa harusnya mendapat banyak kesempatan untuk menggunakan kemampuan pemahamannya untuk berlatih, merumuskan, dan memecahkan masalah. Dapat dikatakan bahwa siswa yang kurang mendapatkan latihan dan pembiasaan mengerjakan soal-soal, akan mempengaruhi kemampuan pemahaman matematis dan akan berdampak pada kemampuan matematis lainnya.

\section{KESIMPULAN}

Berdasarkan hasil dan pembahasan, terlihat bahwa masih sedikit siswa yang bisa menyelesaikan soal tes kemampuam pemahaman matematik, ini bisa diketahui dari presentase pada setiap indikator. Adapun presentase tertingi pada soal pemahaman matematik pada indikator memberikan contoh dan non contoh sebesar 65,78\%. Sedangkan presentase kemampuan pemecahan masalah matematik terbesar yang di peroleh dari indikator memahami masalah sebesar $14,73 \%$.

Beberapa kesalahan siswa dalam mengerjakan soal tes antara lain: 
1. Tidak memahami konsep dasar

2. Miskonsepsi antara informasi yang diberikan dengan yang ditangkap siswa

3. Kesalahan dalam membedakan konsep satu dengan konsep lainnya

4. Kesalahan membedakan contoh dan non contoh

Dengan demikian hasil analisis kemampuan pemahaman dan pemecahan masalah matematik siswa MTs kecamatan Cianjur masih tergolong rendah. Maka dari itu guru perlu merancang kegiatan belajar mengajar dikelas agar lebih inovatif dan lebih banyak lagi memberikan soalsoal kemampuan pemahaman dan pemecahan masalah sebagai stimulus agar kemampuan pemahaman dan pemecahan masalah terus mening

\section{UCAPAN TERIMA KASIH}

Penulis mengucapkan terimakasih kepada semua pihak yang telah berkontribusi dalam pembuatan hasil penelitian ini.

\section{DAFTAR PUSTAKA}

Agus, I. K., Artana, B., Wirya, I. N., \& Wibawa, I. C. (2014). Pengaruh Strategi React Terhadap Kemampuan Pemecahan Masalah Matematika Siswa Kelas IV SD 2 Paket Agung, 2(1).

Aripin, U. (2016). Meningkatkan Kemampuan Pemahaman Matematik Siswa SMP melalui Pendekatan Pembelajaran Berbasis Masalah. P2M STKIP Siliwangi, 2(1), 120-127.

Dini, M., Wijaya, T. T., \& Sugandi, A. I. (2017). Pengaruh Self Confidence terhadap Kemampuan Pemahaman Matematik Siswa SMP. Jurnal Silogisme, 2(2), 56-60.

Hendriana, H., \& Sumarmo, U. (2014). Penilaian Pembelajaran Matematika. Bandung: Refika Aditama.

Muchlis, E. E. (2012). Pengaruh pendekatan pendidikan matematika realistik indonesia (PMRI) terhadap perkembangan kemampuan pemecahan masalah siswa kelas II SD Kartika 1.01 Padang. Jurnal Exacta, X(2), 1-4.

Mulyanti, N. R., Yani, N., \& Amelia, R. (2018). Analisis kesulitan siswa dalam pemecahan masalah matematik siswa smp pada materi teorema phytagoras, 1(3), 415-426.

Murnaka, N. P., \& Dewi, S. R. (2018). Penerapan Metode Pembelajaran Guided Inquiry untuk Meningkatkan Kemampuan Pemahaman Konsep Matematis. Journal of Medives: Journal of Mathematics Education IKIP Veteran Semarang, 2(2), 163-171.

Nur, A. S., \& Rahman, A. (2013). Mathematics Problem Solving as a Medium to Develop a Formal Reasoning at Student of Junior High School. Jurnal Sainsmat, Vol. 2(1), 84-92.

Puspitasari, I., Purwasih, R., Nurjaman, A., \& Wahyuni, S. (2017). Analisis Hambatan Belajar Mahasiswa Pada Mata Kuliah Program Linear. JIPM (Jurnal Ilmiah Pendidikan Matematika), 6(1), 39-46.

Putra, H. D., Setiawan, H., Nurdianti, D., Retta, I., \& Desi, A. (2018). Kemampuan Pemahaman Matematis Siswa SMP di Bandung Barat. Jurnal Pendidikan Matematika, 
974 Sari, Rismayanti, \& Puspitasari, Analisis Kemampuan Pemahaman dan.....

$11(1), 1-12$.

Rohaeti, E. E. (2012). Analisis pembelajaran konsep esensial matematika sekolah menengah melalui pendekatan kontekstual socrates. Infinity: Jurnal Ilmiah Program Studi Matematika STKIP Siliwangi Bandung, 1(2), 186-191.

Sari, S., Elniati, S., \& Fauzan, A. (2014). Pengaruh Pendekatan Pembelajaran Berbasis Masalah Terhadap Kemampuan Pemecahan Masalah Matematika Siswa Kelas Viii Smp Negeri 1 Padang Tahun Pelajaran 2013 / 2014. Jurnal Pendidikan Matematika, 3(2), 5459.

Sariningsih, R. (2014). Pendekatan kontekstual untuk meningkatkan kemampuan pemahaman matematis siswa smp. Infinity: Jurnal Ilmiah Program Studi Matematika STKIP Siliwangi Bandung, 3(2), 150-163.

Sundayana, R. (2016). Kaitan antara Gaya Belajar, Kemandirian Belajar, dan Kemampuan Pemecahan Masalah Siswa SMP dalam Pelajaran Matematika. Mosharafa: Jurnal Pendidikan Matematika, 5(2), 75-84.

Tiun, P. K., Hudiono, B., \& Hartoyo, A. (2014). Kemampuan Pemecahan Masalah Dan Komunikasi Matematis Siswa Menyelesaikan Soal Cerita Materi Pecahan di SMP. Jurnal Pendidikan dan Pembelajaran, 3(8), 1-10.

Yuhani, A., Zanthy, L. S., \& Hendriana, H. (2018). Pengaruh Pembelajaran Berbasis Masalah terhadap Kemampuan Pemecahan Masalah Matematis Siswa SMP. JPMI (Jurnal Pembelajaran Matematika Inovatif, 1(3), 445-452. 